\title{
EXPLORING EFL UNDERGRADUATE STUDENTS' INSIGHT TOWARD ONLINE ENGLISH LEARNING QUALITY DURING COVID-19 PANDEMIC
}

\author{
Dinda Ismu Asyifa \\ Universiti Putra Malaysia \\ dindadia271@gmail.com
}

\begin{abstract}
COVID-19 disease has hit many countries since 2020. In this pandemic era, every field must getting used to technology things, such as online learning and teaching activities. Even though the educational field is facing the pandemic, it does not mean the quality of teaching and learning is not upgraded. This study aimed to find EFL undergraduate students' insight toward the quality of online English learning during COVID-19 pandemic. There were 60 participants from this study, 30 from English major and 30 from non-English major. However, EFL students with English and non-English major thought that the quality of English online learning is good enough. In addition, government, institutions, and lecturers must work together to keep and increase the quality of online English learning.
\end{abstract}

Keyword: Online english learning, online learning quality, students' insight

\section{INTRODUCTION}

On the 11 of March 2020, the World Health Organization (WHO) confirmed that COVID-19 as the pandemic because of its spread. In Indonesia's case, to prevent this infectious disease, the government made new rules such as restricted work activities, public facilties, and school activities (Putri, 2020). These restrictions make all activities change, especially for educational field. Students who usually learn face to face must be changed into online learning synchronously or asynchronously at home. This issue can change the quality of learning, which students can easily understand the materials when teachers explain it directly, but students must learn online at home now. It would make students feeling hard in learning activities.

In line with this issue, some experts stated that there are challenges in teaching and learning English online during the COVID-19 pandemic. On Mahyoob (2020) stated that on his research, more than $30 \%$ of college students missed the essential things in the educational activities, such as missed many tasks, duties, and communication with lecturers, which these negative challenges influenced online English learning during COVID-19 pandemic. Another online English learning issue from Indonesia, Agung (2020), stated that $66.7 \%$ of students felt not enthusiastic about online learning. In addition, the task given to students makes them felt down. They thought that the abundance of assignments given would kill them because many lecturers gave the assignments. This issue is essential, where lecturers should give materials or fun activities to enhance the quality of online English learning instead of giving many assignments that can make students feel down or stressed. In order to enhance the quality of online English learning, on Sakkir's (2020) research, students felt so fun with English online learning by using the media. They felt enthusiastic about learning English because the lecturers used the media such as Zoom, Youtube, Google classroom, etc. to teach the students. Thus, many challenges happened for teaching and learning English online, but even though the world 
is in the pandemic, it does not mean English learning quality is not improved. Universities and lecturers have a vital role in enhancing the quality of online English learning during COVID19 pandemic.

However, related to the challenges and issues faced in online English learning in the university context, it is essential to see the quality of online English learning during COVID19 pandemic whether keep well or not. However, this research explores EFL undergraduate students' insight toward online English learning during the COVID-19 pandemic in Indonesia to see the quality of online English learning based on university facilities, lecturers' teaching ways, and materials from English non-English majors.

The researcher formulates three research questions as follows: 1) What is EFL undergraduate students with English majors' insight toward online English learning quality during COVID-19 pandemic?, 2) What is EFL undergraduate students with non-English majors' insight toward online English learning quality during COVID-19 pandemic?, and 3) Is there any different insight between English and non-English majors toward online English learning quality during the COVID-19 pandemic?

\section{METHOD}

This research used quantitative descriptive research, which applying survey design. According to Cohen (2018), Quantitative research tests a hypothesis, tests numerical data, procedural objectivity, and statistically related matters. However, survey design was applied for this research to explore the information about opinion from group of people. There were 60 participants from Indonesia undergraduate students from English major (30 students) and nonEnglish major (30 students) who get English class in university during Covid-19 pandemic outbreak. The researcher used online questionnaire to reveal the quality of English online learning during Covid-19. Thus, the questionnaire was adapted from two experts, Maier (2010) and Otter (2013) and has been validated by expert validation. This instruments was constructed from some parts of university quality standard such lecturer expert in technology, university facilty, lecturers-students communication, etc. There were 17 items from the questionnaire to answer research question. The researcher used Likert scale for questionnaire (srongly disagree, disagree, agree, strongly agree). In order to gather the data, Google form would be used and the researcher shared it to social media (Whatsapp, Instagram, Facebook, etc.) for three weeks. The data were analyzed by using SPSS ver 25 to find the highest percentage and mean of Indonesian undergraduate students toward the quality of English online learning during Covid19. After that, researcher did the independent T-test to find significant difference between English major and non-English major insight toward the quality of online English learning.

\section{FINDINGS AND DISCUSSION}

\section{Findings}

This section divides into three sub-sections. The first is reliability statistics explains about the reliability of instrument. The second section is about EFL undergraduate students' insight of the quality of online English learning during COVID-19 pandemic. The last section explores the significant difference the quality of online English learning between English major and non-English major. Below the details:

\section{Reliability statistics}

Table 1: reliability statistics

\begin{tabular}{r|r}
$\begin{array}{c}\text { Cronbach's } \\
\text { Alpha }\end{array}$ & N of Items \\
\hline .653 & 17 \\
\hline
\end{tabular}


Cronbach alpha was counted in order to see the reliability of rating scale. On the reliability statistics table (see table 1 above), score of $\alpha$. was 0.653 , it means the result of $\alpha$. was adequate reliable. This statement supported by Vaske (2017), an alpha started from .65 .80 is considered as "adequate" or enough for a research of human dimensions that used scale.

\section{EFL Undegraduate Students' Insight}

To explore EFL undergraduate students' insight of online English learning quality, the close-ended questionnaire consisted of 17 items was used. The questionnaire used four scale; Strongly Disagree (SD), Disagree (D), Agree (A), Strongly Agree (SA) which every statements did not have wrong or correct answer. There are 60 EFL undergraduate students have filled their insight honestly in the questionnaire. 30 of them are from English major and 30 of them are from non English major. The result as follow:

\section{Table 2: EFL Undergraduate English Major Insight}

\begin{tabular}{|c|c|c|c|c|c|}
\hline Statements & M & SD & D & $\mathbf{A}$ & SA \\
\hline $\begin{array}{l}\text { During online English learning, my lecturers create chat } \\
\text { group for communication and interaction between } \\
\text { lecturers and students }\end{array}$ & 3.47 & $0 \%$ & $0 \%$ & $53.3 \%$ & $46.7 \%$ \\
\hline $\begin{array}{l}\text { Online English learning materials given clearly and well } \\
\text { structured }\end{array}$ & 2.87 & $0 \%$ & $20.0 \%$ & $73.3 \%$ & $6.7 \%$ \\
\hline $\begin{array}{l}\text { Online English learning materials easy to accessed or } \\
\text { find }\end{array}$ & 3.17 & $3.3 \%$ & $3.3 \%$ & $66.7 \%$ & $26.7 \%$ \\
\hline $\begin{array}{l}\text { I get many assignments than learning the materials in } \\
\text { online English learning }\end{array}$ & 3.20 & $3.3 \%$ & $6.7 \%$ & $56.7 \%$ & $33.3 \%$ \\
\hline $\begin{array}{l}\text { University gives the facility such as give internet data } \\
\text { for me to learn English online }\end{array}$ & 2.63 & $\begin{array}{c}16.7 \\
\%\end{array}$ & $23.3 \%$ & $40.0 \%$ & $20.0 \%$ \\
\hline $\begin{array}{l}\text { My lecturers have high expertise in implementing } \\
\text { online English learning }\end{array}$ & 2.97 & $0 \%$ & $3.3 \%$ & $96.7 \%$ & $0 \%$ \\
\hline $\begin{array}{l}\text { My lecturers give me fast feedback through email, chat, } \\
\text { or group when i ask related to English learning }\end{array}$ & 2.97 & $0 \%$ & $10.0 \%$ & $83.3 \%$ & $6.7 \%$ \\
\hline $\begin{array}{l}\text { I can exchange knowledge with another student easily } \\
\text { and quickly through email, chat, chatgroup, etc }\end{array}$ & 2.97 & $3.3 \%$ & $13.3 \%$ & $66.7 \%$ & $16.7 \%$ \\
\hline $\begin{array}{l}\text { Online group communication facilitates me in learning } \\
\text { English online }\end{array}$ & 3.13 & $0 \%$ & $6.7 \%$ & $73.3 \%$ & $20.0 \%$ \\
\hline Group work is effective for online English learning & 2.60 & $6.7 \%$ & $40.0 \%$ & $40.0 \%$ & $13.3 \%$ \\
\hline $\begin{array}{l}\text { From online English learning, I get knowledge } \\
\text { (conceptual knowledge) }\end{array}$ & 2.90 & $3.3 \%$ & $13.3 \%$ & $73.3 \%$ & $10.0 \%$ \\
\hline $\begin{array}{l}\text { Online English learning enhance my English skills } \\
\text { (reading, writing,listening, and speaking) }\end{array}$ & 2.80 & $3.3 \%$ & $23.3 \%$ & $63.3 \%$ & $10.0 \%$ \\
\hline $\begin{array}{l}\text { Online English learning provided better learning than } \\
\text { face to face learning }\end{array}$ & 2.23 & $\begin{array}{c}16.7 \\
\%\end{array}$ & $46.7 \%$ & $33.3 \%$ & $3.3 \%$ \\
\hline $\begin{array}{l}\text { I feel I receive teaching in good quality in online } \\
\text { English learning }\end{array}$ & 2.73 & $0 \%$ & $36.7 \%$ & $53.3 \%$ & $10.0 \%$ \\
\hline I feel I can cheat easily in English online learning & 2.87 & $\begin{array}{c}10.0 \\
\%\end{array}$ & $13.3 \%$ & $56.7 \%$ & $20.0 \%$ \\
\hline $\begin{array}{l}\text { The quality of online English learning offered in my } \\
\text { university is good }\end{array}$ & 3.03 & $0 \%$ & $6.7 \%$ & $83.3 \%$ & $10.0 \%$ \\
\hline $\begin{array}{l}\text { I feel satisfied in online English learning offered in my } \\
\text { university }\end{array}$ & 2.9 & $0 \%$ & $23.3 \%$ & $63.3 \%$ & $13.3 \%$ \\
\hline
\end{tabular}

From the result above, it can be concluded that EFL undergraduate students English majors thought that the quality of online English learning offered in their university was good 
but is still need improvement. It is proved by the statements of students that most of students $(63.3 \%)$ stated that they disagree in statement "I feel satisfied in online English learning offered in university" but, some of them (23.3\%) stated disagree. In addition, most students $(53.3 \%)$ stated that they received good quality in online English learning, but some stated that $36.7 \%$ disagreed. This might be because online learning gave assignment. Most of students $(56.7 \%)$ stated agreed that they got many assignments. In the other hands, some parts of universities quality for online English learning is well, which are 53.3\% students agree that communication between lecturers and students have facilitated with group, $66.7 \%$ of students agree that online material is well, and $96.7 \%$ of students agree that the lecturers already have high expertise in implementing online English learning.

\section{Table 3: EFL Undergraduate non-English Major Insight}

\begin{tabular}{|c|c|c|c|c|}
\hline Statements & SD & D & $\mathbf{A}$ & SA \\
\hline $\begin{array}{l}\text { During online English learning, my lecturers create chat } \\
\text { group for communication and interaction between } \\
\text { lecturers and students }\end{array}$ & $3.3 \%$ & $10.0 \%$ & $63.3 \%$ & $23.3 \%$ \\
\hline $\begin{array}{l}\text { Online English learning materials given clearly and well } \\
\text { structured }\end{array}$ & $10.0 \%$ & $16.7 \%$ & $63.3 \%$ & $10.0 \%$ \\
\hline $\begin{array}{l}\text { Online English learning materials easy to accessed or } \\
\text { find }\end{array}$ & $0 \%$ & $13.3 \%$ & $66.7 \%$ & $20.0 \%$ \\
\hline $\begin{array}{l}\text { I get many assignments than learning the materials in } \\
\text { online English learning }\end{array}$ & $0 \%$ & $36.7 \%$ & $53.3 \%$ & $10.0 \%$ \\
\hline $\begin{array}{l}\text { University gives the facility such as give internet data } \\
\text { for me to learn English online }\end{array}$ & $20.0 \%$ & $26.7 \%$ & $50.0 \%$ & $3.3 \%$ \\
\hline $\begin{array}{l}\text { My lecturers have high expertise in implementing } \\
\text { online English learning }\end{array}$ & $3.3 \%$ & $10.0 \%$ & $80.0 \%$ & $6.7 \%$ \\
\hline $\begin{array}{l}\text { My lecturers give me fast feedback through email, chat, } \\
\text { or group when i ask related to English learning }\end{array}$ & $3.3 \%$ & $16.7 \%$ & $66.7 \%$ & $13.3 \%$ \\
\hline $\begin{array}{l}\text { I can exchange knowledge with another student easily } \\
\text { and quickly through email, chat, chatgroup, etc }\end{array}$ & $3.3 \%$ & $13.3 \%$ & $70.0 \%$ & $13.3 \%$ \\
\hline $\begin{array}{l}\text { Online group communication facilitates me in learning } \\
\text { English online }\end{array}$ & $3.3 \%$ & $13.3 \%$ & $73.3 \%$ & $10.0 \%$ \\
\hline Group work is effective for online English learning & $0 \%$ & $30.0 \%$ & $63.3 \%$ & $6.7 \%$ \\
\hline $\begin{array}{l}\text { From online English learning, I get knowledge } \\
\text { (conceptual knowledge) }\end{array}$ & $6.7 \%$ & $16.7 \%$ & $70.0 \%$ & $6.7 \%$ \\
\hline $\begin{array}{l}\text { Online English learning enhance my English skills } \\
\text { (reading, writing,listening, and speaking) }\end{array}$ & $6.7 \%$ & $16.7 \%$ & $66.7 \%$ & $10.0 \%$ \\
\hline $\begin{array}{l}\text { Online English learning provided better learning than } \\
\text { face to face learning }\end{array}$ & $10.0 \%$ & $53.3 \%$ & $36.7 \%$ & $0 \%$ \\
\hline $\begin{array}{l}\text { I feel I receive teaching in good quality in online } \\
\text { English learning }\end{array}$ & $3.3 \%$ & $33.3 \%$ & $63.3 \%$ & $0 \%$ \\
\hline I feel I can cheat easily in English online learning & $10.0 \%$ & $30.0 \%$ & $46.7 \%$ & $13.3 \%$ \\
\hline $\begin{array}{l}\text { The quality of online English learning offered in my } \\
\text { university is good }\end{array}$ & $10.0 \%$ & $10.0 \%$ & $80.0 \%$ & $0 \%$ \\
\hline $\begin{array}{l}\text { I feel satisfied in online English learning offered in my } \\
\text { university }\end{array}$ & $3.3 \%$ & $30.0 \%$ & $60.0 \%$ & $6.7 \%$ \\
\hline
\end{tabular}

The result above showed that EFL undergraduate students thought that the quality of online English learning offered in their university is good. It is proved by the statements of student stated that the lecturers already have high skill in implementing online English learning, lecturers' feedback response, online English materials, online group communication, and the facility provided by institution. They felt satisfied with online English learning offered in their university, but $30.0 \%$ disagreed with this statement. In the other sides, there is still a worst 
tendency of EFL undergraduate students insight toward online English learning during pandemic. Students' statement proves that $53.3 \%$ of students stated that they disagree with the statement that online English learning provides better learning than face-to-face learning. This might happen because the quality of online English learning in university needed to be improved. In addition, $53.3 \%$ of students agree that they got many assignments instead of learning material. This issue is essential, students must get balanced learning between material and assignment, so they do not feel hard or uncomfortable with online English learning. Gave students many assignment during online learning will increase their desire to cheat in many ways. From this result, $46.7 \%$ students agree that they can easily cheating in online English learning.

These issues above lineswith Maqableh (2021), which in his research, students still feel dissatisfied with online English learning in university because of internet connectivity, interaction between lecturer to students, many assignments, etc. It is like a common thing for universities to have problem during this pandemic. On Kapasia's research (2020), students felt not interested in lecturers' teaching ways, students have internet connection problem, students' environment to study, etc. Thus, Maqableh (2021) suggested that every education institution should use an online learning platform and create a management system to online class live where students can interact with lecturers, share materials, and score online to make students feel satisfied. Governor and institution should help students in learning activities such give them internet data and provide laptop. In addition, university should create evaluation team such academic continuity planning committee (ACPC) to review, monitor, and evaluate online learning in university.

In line with this suggestion, Kapasia (2020) stated that university and lecturers create a continuity plan to make sure that online English learning continues. Lecturers can also adopt digital open source learning and learning management system. Funding for institutional needed to improve educational system such as improving the capability of stakeholder of institution. Not only for the stakeholder, students also need funding to support them in online learning such giving them internet data. This statement supported by George (2020) which stated that internet access is an essential thing that cannot be ignored for online learning which by using the internet, students do not have interference when doing exams without any interruptions.

It can be concluded that having learning problems during pandemic is a common thing that every institution faces, such as internet connection, lecturers' ability in online teaching, etc. Thus, it is not a reason for university does not increase its quality in online learning. Government, institution, and lecturer must work together to keep and increase the learning quality during pandemic, such as creating an online learning system, creating an evaluation team to monitor and review online learning, giving students funding assistant or internet data, etc.

\section{Indipendent T-test}

From the table below, the result was analyzed using an independent sample t-test to compare the quality in online English learning both English major and non English major. The result showed sig. (2-tailed) $<0.05$ or $0.021<0.05$ and t-table $>\mathrm{t}$-count or $2.376>1.672$ it means that the hypothesis was accepted and there is significant difference in the quality of online English learning between English major and non-English major.

\begin{tabular}{|l|c|c|}
\hline \multicolumn{2}{|c|}{ Table 4: Independent Sample T-Test } \\
Independent Sample T-Test \\
\hline \\
$\begin{array}{c}\text { Levene's } \\
\text { Test for }\end{array}$ & t-test for Equality of Means \\
\hline
\end{tabular}




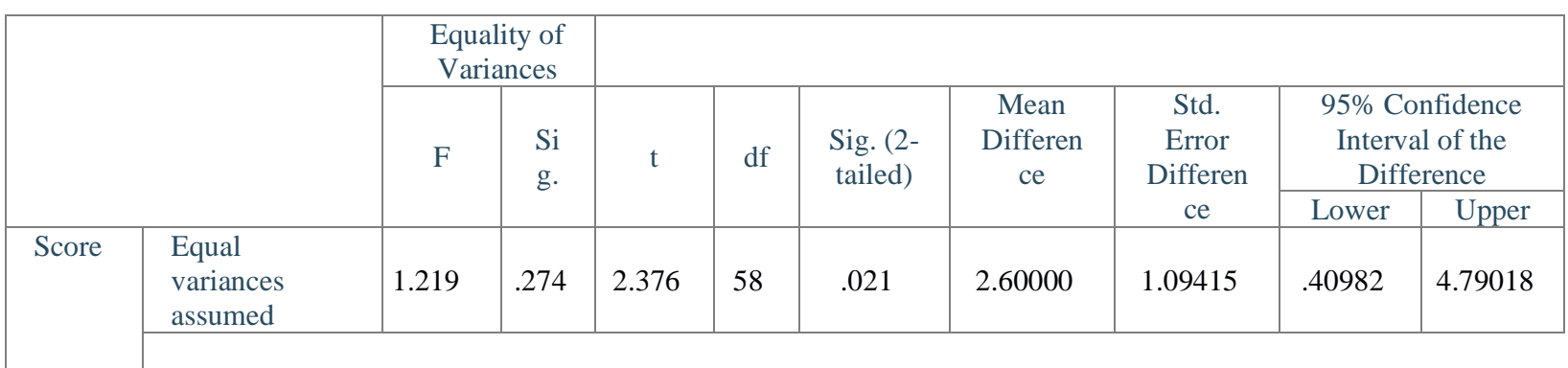

\section{Discussion}

COVID-19 disease has hit many countries since 2020. In this pandemic era, every field must get used to technology, such as online learning and teaching activities. This means that every lecturer and student must be familiar with technology. Thus, lecturers must think about the effective way to utilize the technology in online teaching activities such as improve self-ability in using learning media, provide structures online materials, planning good learning to reduce students or opening references when online exercises are carried out. In addition, students also must utilize technology for learning process instead of abusing technology to cheat.

Institution has an essential role in supporting learning and teaching activities, such as proving tuition assistance for students or internet data for learning. Even though institutions are in the pandemic era nowadays, it does not mean the quality for English learning is not improved. However, government, institution, lecturers, and institution have to work together to increase the quality of online English learning.

\section{CONCLUSION}

According to the survey filled by English major and non-English major students, it can be concluded that students already felt satisfied with online English learning offered by universities during the COVID-19 pandemic. In another hand, there is still a tendency that universities and lecturers still must increase their quality in online English learning. Thus, there is a significant difference in the quality of online English learning between English and nonEnglish majors. There are some ways in order to increase online English learning quality, such increase lecturers' online teaching skill so students do not feel bored or monotone, give facility for students like internet data for their online English learning, create group communication to make communication between lecturers and students easily, etc.

\section{REFERENCES}

Agung, A. S. S. N., Surtikanti, M. W., \& Quinones, C. A. (2020). Students' Perception of Online Learning during COVID-19 Pandemic: A Case Study on the English Students of STKIP Pamane Talino. SOSHUM: Jurnal Sosial Dan Humaniora, 10(2), 225-235. https://doi.org/10.31940/soshum.v10i2.1316

Alawamleh, M., Al-Twait, L. M., \& Al-Saht, G. R. (2020). The effect of online learning on communication between instructors and students during Covid-19 pandemic. Asian Education and Development Studies, August. https://doi.org/10.1108/AEDS-06-20200131 
Cohen, L., Manion, L., \& Morrison, K. (2018). Research Method in Education (8th editio). Routledge.

George, M. L. (2020). Effective Teaching and Examination Strategies for Undergraduate Learning During COVID-19 School Restrictions. Journal of Educational Technology Systems, 49(1), 23-48. https://doi.org/10.1177/0047239520934017

Kapasia, N., Paul, P., Roy, A., Saha, J., Zaveri, A., Mallick, R., Barman, B., Das, P., \& Chouhan, P. (2020). Impact of lockdown on learning status of undergraduate and postgraduate students during COVID-19 pandemic in West Bengal, India. Children and Youth Services Review, 116, 105194. https://doi.org/10.1016/j.childyouth.2020.105194

Mahyoob, M. (2020). Challenges of e-Learning during the COVID-19 Pandemic Experienced by EFL Learners. Arab World English Journal, 11(4), 351-362. https://doi.org/10.24093/awej/vol11no4.23

Maqableh, M., \& Alia, M. (2021). Evaluation online learning of undergraduate students under lockdown amidst COVID-19 Pandemic: The online learning experience and students' satisfaction. Children and Youth Services Review, 128(August 2020), 106160. https://doi.org/10.1016/j.childyouth.2021.106160

Otter, R. R., Seipel, S., Graeff, T., Alexander, B., Boraiko, C., Gray, J., Petersen, K., \& Sadler, K. (2013). Comparing student and faculty perceptions of online and traditional courses. Internet and Higher Education, 19, 27-35. https://doi.org/10.1016/j.iheduc.2013.08.001

Paechter, M., \& Maier, B. (2010). Online or face-to-face? Students' experiences and preferences in e-learning. Internet and Higher Education, 13(4), 292-297. https://doi.org/10.1016/j.iheduc.2010.09.004

Putri, R. N. (2020). Indonesia dalam Menghadapi Pandemi Covid-19. Jurnal Ilmiah Universitas Batanghari Jambi, 20(2), 705. https://doi.org/10.33087/jiubj.v20i2.1010

Sakkir, G., Dollah, S., \& Ahmad, J. (2020). Favorite E-Learning Media in Pandemic Covid-19 Era (Universitas Muhammadiyah Sidenreng Rappang). Jurnal Studi Guru Dan Pembelajaran, 3(3), 480-485. https://www.e-journal.my.id/jsgp/article/view/435

Vaske, J. J., Beaman, J., \& Sponarski, C. C. (2017). Rethinking Internal Consistency in Cronbach's Alpha. Leisure Sciences, 39(2), 163-173. https://doi.org/10.1080/01490400.2015.1127189 